\title{
Exploring the Response of Net Primary Productivity Variations to Land Use/Land Cover Change: A Case Study in Anhui, China
}

\author{
Hongfei Yang ${ }^{1,2}$, Dandan Hu${ }^{1}$, Fei Peng ${ }^{3}$, Youbao Wang ${ }^{1}$ \\ ${ }^{1}$ College of Life Sciences, Anhui Normal University, Wuhu, Anhui, China \\ ${ }^{2}$ Collaborative Innovation Centre of Recovery and Reconstruction of Degraded Ecosystem in Wanjiang City Belt, \\ Anhui Province, China \\ ${ }^{3}$ Northwest Institute of Eco-Environment and Resources, Chinese Academy of Sciences, Lanzhou, China
}

Received: 11 June 2018

Accepted: 16 September 2018

\begin{abstract}
Land use and land cover change (LUCC) has a significant influence on regional net primary productivity (NPP) in territorial ecosystems. Evaluating the driving factors of LUCC and the influences of LUCC on NPP is significant for understanding the driving mechanisms deeply and improve land management. NPP as estimated by the Carnegie-Ames-Stanford Approach (CASA) model was employed as an important indicator to evaluate the influences of LUCC on regional NPP and decouple interactive effects of LUCC and climate change on NPP in Anhui from 2001 to 2010. The results demonstrated that $34.25 \%$ of the whole area had occurred in LUCC. The most dominant transformation of LUCC was the conversion from grassland and crop/natural vegetation mosaic to forest and cropland. The area of cropland and forest had the most increments compared to other land use types, with an increase of $30.52 \%$ and $35.29 \%$ of that in 2001 . Socio-economic development, economic interests and government policies took an important role in driving the LUCC. The total NPP increased mainly due to the contributions of the area expansion of cropland and forest. Climate change resulted in the decreased NPP of $449.84 \mathrm{GgC}$, whereas LUCC facilitated the NPP in the increase of $1816.05 \mathrm{GgC}$. This result indicates that the increased NPP induced by LUCC could offset the NPP decrease from climate change during the study periods. This paper also demonstrated that reforestation and forest protection were indeed effective in promoting ecosystem productivity.
\end{abstract}

Keywords: LUCC, NPP, driving factors, human intervention, climate change

*e-mail: hongfeiy@ahnu.edu.cn 


\section{Introduction}

Land use/cover is significant to a key land surface process [1] by significantly influencing microclimate [2], soil quality [3], biodiversity [4] and the carbon cycle [5]. Land use/cover is therefore emerging as a key issue in global environmental change $[6,7]$. As an interface between natural conditions and anthropogenic influence, land use and cover change (LUCC) has been recognized as one of the most important factors that influence the environment [8]. In recent decades, since China initiated economic reform and an open-door policy in 1978, rapid LUCC has occurred in most of its territory [9], especially, in the eastern developing regions of China. However, due to population pressures, economic growth, and excessive consumption of natural resources, a large amount of China's primary forests and wetlands has been exhausted, and a large area of its cropland and grassland has been degraded [10]. These human disturbances have resulted in extensive desertification, land degradation, flooding and soil erosion [10]. To protect and improve its environmental conditions, China has implemented a series of vegetation restoration programs, including the Natural Forest Protection Project (NFPP), the Sloping Land Conversion Project (SLCP) and the Grain for Green Program (GGP) [11]. As a result, these ecological restoration projects have brought significant changes in land use and land cover, which caused the conversion of land use types.

Net primary productivity (NPP) is a measure of the net amount of $\mathrm{CO}_{2}$ taken up from the atmosphere via photosynthesis by vegetation per unit area and time, and is a key term in the global carbon cycle and is regarded as the regulator of ecosystem processes and the major determinant of carbon sinks on land [12]. NPP also is the primary source of food for humanity and other heterotrophic organisms on Earth. Consequently, it is critical to characterize the spatial and temporal dynamics of NPP as a result of various driving forces [12, 13]. As an important parameter of ecosystem functioning and the carbon cycle, NPP is mainly influenced by both natural and anthropogenic factors. The most obvious anthropogenic influence on NPP involves LUCC caused by human activities, resulting in changing the natural environment and consequently influencing ecosystem NPP. With its continued or intensified activities, LUCC has been noticed for its important influence on NPP in terrestrial ecosystems $[14,15]$. LUCC leads to changes of vegetation types, which directly influence terrestrial ecosystem NPP. Terrestrial ecosystems play important roles in reducing carbon emissions and offsetting global warming [16, 17]. Hence, quantitative investigations on the influence of LUCC on NPP are important for understanding an ecosystem's function and ability to respond to changes in the physical and social environment [18].

To date, extensive research has been done on LUCCrelated NPP variation in terrestrial ecosystems $[19,20]$. However, a large part of the literature has focused on the influence of urbanization on NPP and the carbon cycle [21-23]. And several studies of LUCC-related NPP variations generally focused on the impacts of climate warming and human activities on NPP [24, 25]. Numerous studies have analyzed the trends and variations in terrestrial vegetation productivity in the past decades $[12,18,26]$. However, because humaninduced LUCC and climate change are two prominent and interacting factors [27, 28], analyses on the relative influences of NPP variations from LUCC by distinguishing the impacts of climate change are very limited. In fact, LUCC could offset or facilitate NPP with substantial influences for terrestrial ecosystem functions [29]. Some studies have focused on understanding the impacts of LUCC on terrestrial productivity and carbon storage without explicitly distinguishing the effects of climate change $[19,30]$.

What are the change characteristics of the regional LUCC in a developing province in eastern parts of China from 2001 to 2010? What are the impacts of LUCC on NPP? Is the situation beneficial for NPP due to the human-induced LUCC? How to understand the respective and the integrated impacts of LUCC and climate change on terrestrial ecosystem productivity? Have the ecological restoration projects produced positive role in improving the regional environmental conditions and vegetation productivity in Anhui over the past ten years? All these questions remain unanswered. As the developing central-eastern area and one of the major afforestation zones of China, Anhui has experienced significant LUCC and consequently has a strong impact on ecosystem productivity due to rapid economic growth and increased human interference. Due to the decade from 2001 to 2010 being a key period for implementing ecological restoration projects in the study area, our primary objectives of this study are to investigate the conversion characteristics of land use and land cover change in Anhui between 2001 and 2010, understand the impact of LUCC on the regional NPP and evaluate the interactive effects of LUCC and climate change on NPP in Anhui from 2001 to 2010.

\section{Materials and Methods}

\section{Study Area}

This research was conducted in Anhui Province (Fig. 1) in eastern China. The region covers an area of $13.96 \times 10^{4} \mathrm{~km}^{2}$ and is located between $29^{\circ} 41^{\prime} \mathrm{N}-34^{\circ} 38^{\prime} \mathrm{N}$ and $114^{\circ} 54^{\prime} \mathrm{E}-119^{\circ} 37^{\prime} \mathrm{E}$, taking up $1.45 \%$ of the whole area of the country. The study region is located across the basins of the Yangtze River and the Huaihe River. The longest extent from east to west is about $430 \mathrm{~km}$ and from north to south about $586 \mathrm{~km}$, respectively. The terrain range is quite diverse topographically, showing decreasing elevation from higher mountains in the southwest to the lower ones in the northeast. The Yangtze River cut across southern Anhui (Fig. 1). Major 


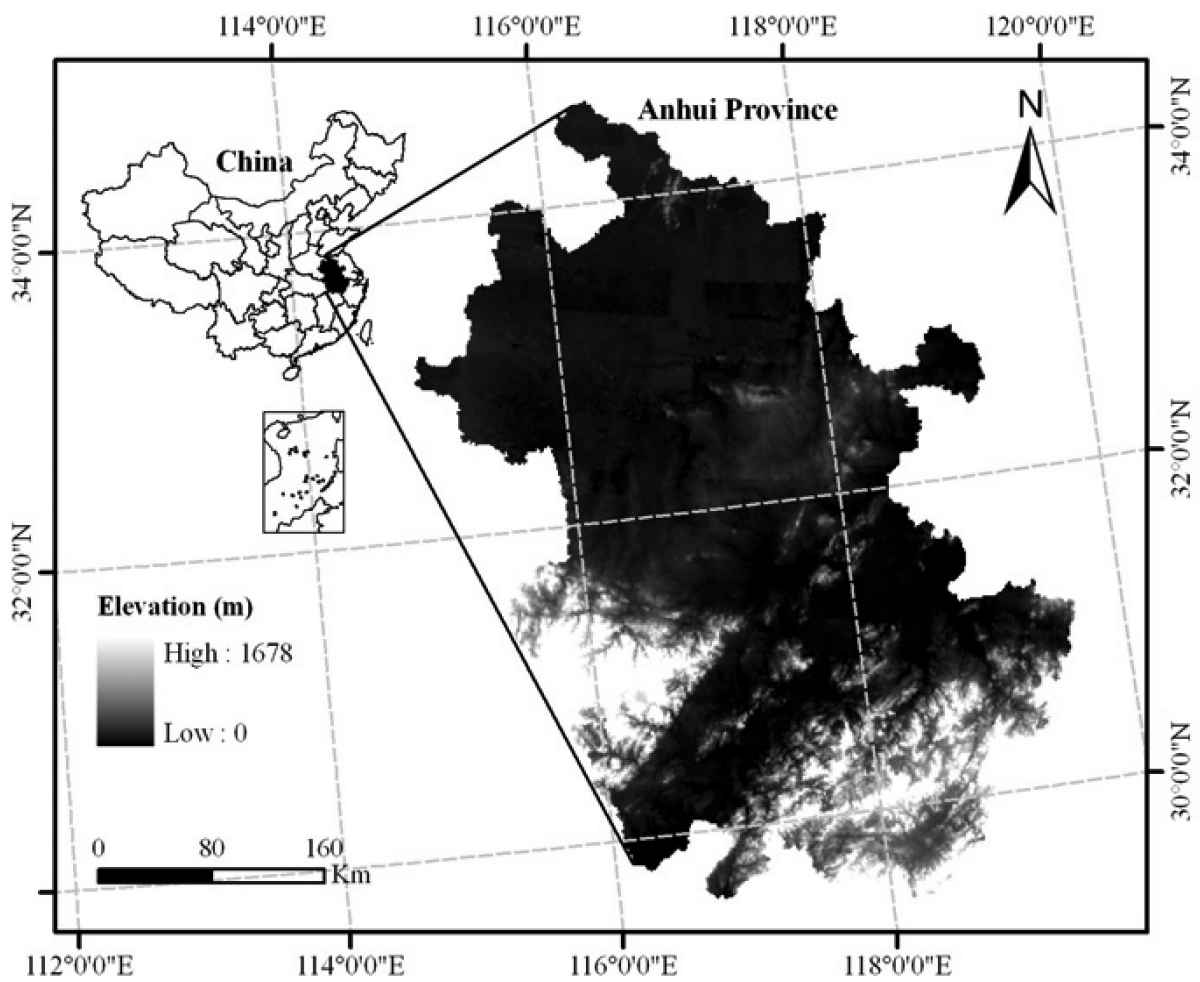

Fig. 1. Geographical location and DEM of the study area.

rivers include the Huaihe in the north and the Yangtze in the south. There are many lakes in the southeastern part of the region near the Yangtze as well (Fig. 1). The local climate features a warm temperate and subtropical climate with an average annual temperature of $14-17^{\circ} \mathrm{C}$, and an annual accumulated temperature $\left(\geq 10^{\circ} \mathrm{C}\right)$ of $4620-5300^{\circ} \mathrm{C}$. The mean annual precipitation is approximately 750 to $1700 \mathrm{~mm}$. Specifically, the annual precipitation normally ranges within $750-800 \mathrm{~mm}$ in the north, $800-1000 \mathrm{~mm}$ in the central part and about $1100-1600 \mathrm{~mm}$ in the south, respectively.

Anhui is close to the Yangtze River Delta economic zone in China, and has obtained rapid economic and social development in recent years. With the population growth and economic development, the substantial land use and land cover types of the region have changed significantly, and human-induced LUCC are now taking tremendous impacts on its productivity. It is therefore important to estimate the regional NPP and assess the impacts of LUCC on NPP in the developing area.

\section{Data Sources and Processing}

Remote sensing (normalized difference vegetation index (NDVI) and land cover data), meteorological, and geographical data were chosen as input parameters to estimate NPP based on the CASA model. The $500 \mathrm{~m}$ 16-day moderate resolution imaging spectroradiometer NDVI data (MOD13A1) and global land cover product (MCD12Q1) for 2001 and 2010 were obtained from http://ladsweb.nascom.nasa.gov/data/search.html. The monthly NDVI were generated by using maximum- value compositing procedure to merge the 16-day NDVI data. These data were reprojected to the Albers equal area projection and WGS84 datum from the original Integerized Sinusoidal Projection using the MODIS reprojection tool and nearest neighbor method resampling using ArcGIS V9.3 (ESRI, California, USA).

Meteorological data employed in this research covered the period 2001 and 2010. The climate dataset was derived from 81 climatological stations in and around Anhui, and was obtained from the China Meteorological Data Sharing Service System (http:// cdc.cma.gov.cn). These data was interpolated by the Kriging interpolation to produce raster images with $500 \mathrm{~m}$ spatial resolution. These prepared meteorological data were used to drive the CASA model.

Annual land use and land cover (LULC) in Anhui from 2001 to 2010 were derived from the MODIS land cover product (MCD12Q1) based on the International Geosphere Biosphere Program (IGBP) global vegetation classification scheme. Eight dominant land cover classes were extracted from the classification scheme with 17 LCLU classes of the International Geosphere Biosphere Programme, including water bodies, forest, grassland, wetlands, cropland, cropland/natural vegetation mosaic, urban/built up, and low vegetation cover land.

\section{NPP Estimation Model}

As it is difficult to measure NPP value at global or regional scales based on field data, estimates of large-scale NPP can be implemented using remote 
sensing data combined with estimation models [40]. Several models have been developed to estimate NPP at global or regional scales, such as statistical models, process-based models, and light use efficiency (LUE) models [31]. In this study, NPP was calculated by the CASA (Carnegie-Ames-Stanford Approach) model, which is a light use efficiency model based on resource balance theory $[18,32]$. In the CASA model, NPP is the product of absorbed photosynthetically active radiation (APAR) and a light-use efficiency factor $(\varepsilon)[18,33]$. Based on MODIS data and meteorological data, the NPP was estimated as follows:

$$
\operatorname{NPP}(x, t)=\operatorname{APAR}(x, t) \times \varepsilon(x, t)
$$

...where $\operatorname{NPP}(x, t)$ represents $\operatorname{NPP}$ in the geographic coordinate of a given location $x$ and time $t$. $\operatorname{APAR}(x, t)$ is the canopy-absorbed incident solar radiation integrated by pixel $x$ in $t$ time $\left(\mathrm{MJ} \mathrm{m}^{-2}\right)$, and $\varepsilon(x, t)$ represents the actual light use efficiency $\left(\mathrm{g} \mathrm{C} \mathrm{MJ}^{-1}\right)$ of pixel $x$ in $t$ time. $\operatorname{APAR}(x, t)$ is calculated using Eq. (2), as in the following:

$$
A P A R(x, t)=\operatorname{SOL}(x, t) \times F P A R(x, t) \times 0.5
$$

...where $\operatorname{SOL}(x, t)$ is total solar radiation $\left(\mathrm{MJ} \mathrm{m} \mathrm{m}^{-2}\right)$ of pixel $x$ in $t$ time. $\operatorname{FPAR}(x, t)$ is the fraction of the photosynthetically active radiation absorbed by vegetation canopy, and it can be determined by NDVI; 0.5 represents the fraction of total solar radiation available for vegetation (wave-length $0.38-0.71 \mu \mathrm{m}$ ). $\varepsilon(x, t)$ can be expressed by the following equation (Eq. 3):

$$
\varepsilon(x, t)=T_{\varepsilon 1}(x, t) \times T_{\varepsilon 2}(x, t) \times W_{\varepsilon}(x, t) \times \varepsilon_{\max }
$$

...where $\mathrm{T}_{\varepsilon 1}(x, t)$ and $\mathrm{T}_{\varepsilon 2}(x, t)$ represent temperature stress coefficients that reflect the reduction of light-use efficiency caused by temperature factor. $\mathrm{W}_{\varepsilon}(x, t)$ is the moisture stress coefficient that indicates the reduction of light-use efficiency caused by moisture factor. $\varepsilon_{\max }$ represents the maximum light-use efficiency under ideal conditions. More detailed descriptions on CASA model framework can be found in Potter et al. [18, 34].

\section{Field Measurement of NPP}

In order to validate the accuracy of the CASA model, we verified the NPP estimated by the model using field-measured NPP values for Anhui (41 data points; the validation points used were mainly in grassland areas) from April to August 2010. In the study, five small quadrats $(2 \times 2 \mathrm{~m})$ at each sample site $(10 \times 10 \mathrm{~m})$ for grasslands were set and sampled. All plants in each quadrat were harvested to measure aboveground biomass. To determine underground biomass, nine soil cores $(8 \mathrm{~cm}$ diameter) were used to collect samples at

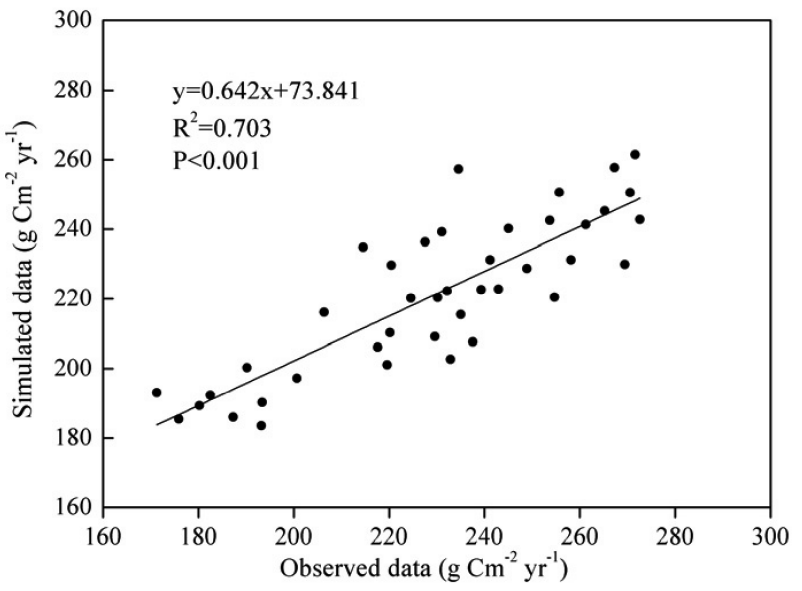

Fig. 2. Validation of CASA model through analyzing the correlation between simulated NPP and field observed NPP for Anhui Province.

$10 \mathrm{~cm}$ intervals. Root samples were soaked in deionized water and cleaned in the laboratory. Biomass samples of all the plants taken from the field were oven-dried at $65^{\circ} \mathrm{C}$ to a constant mass. Afterward, the biomass was converted to carbon content using a conversion factor of 0.45 , which was the grassland NPP.

\section{Validation of CASA Model}

The observed NPP measured by field sampling was compared with the simulated NPP to verify the accuracy of the CASA model. Fig. 2 presents the correlation between the observed NPP and the estimated NPP $\left(\mathrm{R}^{2}=0.703, \mathrm{P}<0.001\right)$, which indicates that the model had a satisfactory estimation accuracy and that the CASA model could be utilized to support research on changes in NPP in the study area.

\section{Results}

\section{Land Use and Land Cover Change during the Study Periods}

\section{Spatial Distribution of Land Use and Land Cover Change}

Cropland, forest and crop/natural vegetation mosaic are the largest and most widely distributed types of land use/cover in Anhui (Fig. 3). Cropland is mainly located in the north central region of the study area. Forest is mainly located in the southern and southwestern mountains of Anhui. The crop/natural vegetation mosaic is mainly located in the transition zone between hills and plains of central parts in the study area. Grassland is sporadically located in the central and southern mountains and hills within the transition zone between the mountains and plains. Wetlands are mainly distributed along the Yangtze in the study area (Fig. 3). 

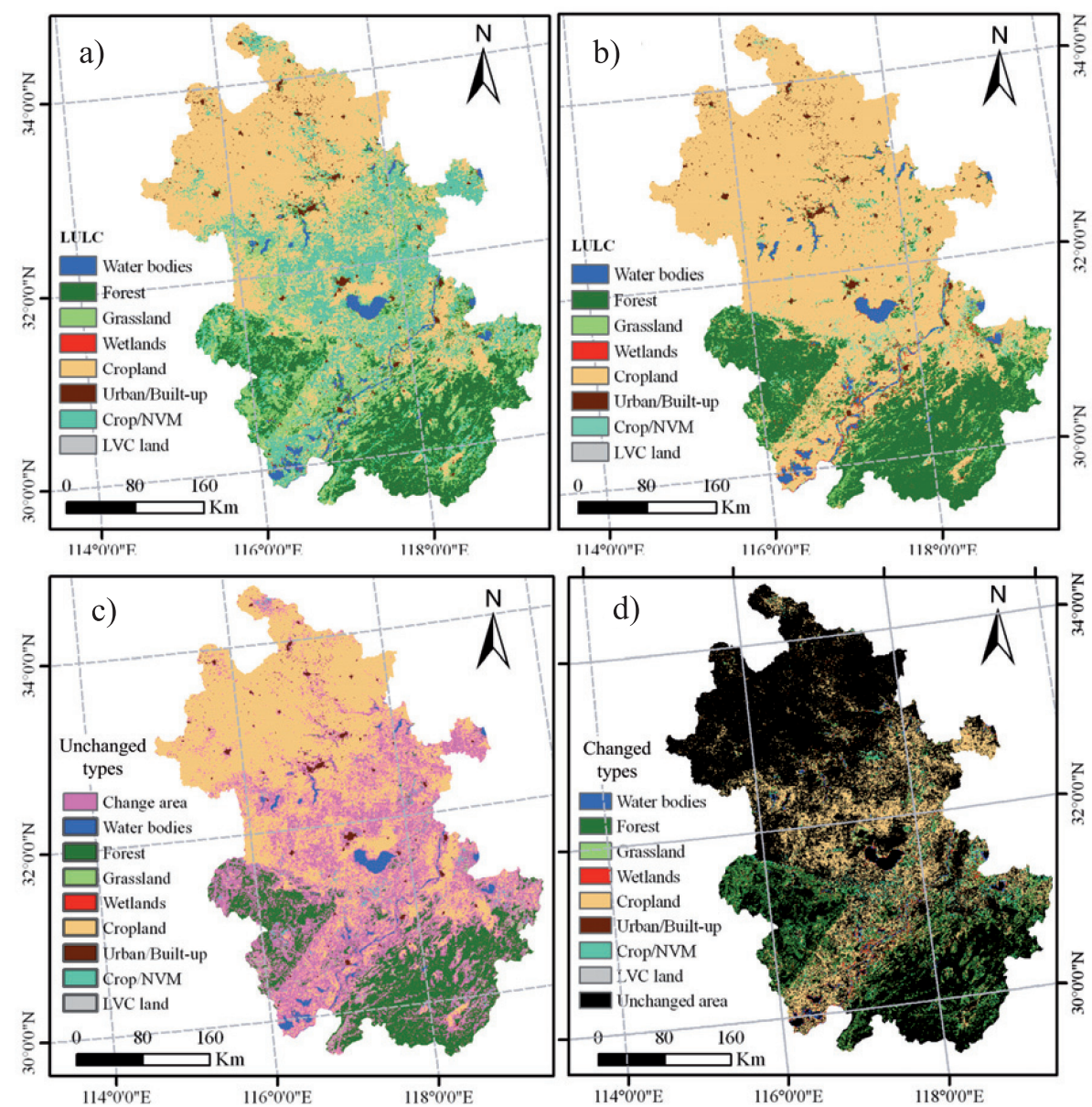

Fig. 3. Land use and land cover maps for 2001 a) and 2010 b), and unchanged c) and changed d) types of LUCC in the different cover types from 2001 to 2010; crop/NVM and LVC land present crop/natural vegetation mosaic and low vegetation cover land, respectively.

The land use and land cover maps for 2001 and 2010 produced from MODIS images are shown in Fig. 3. Land use and land cover change (LULCC) in Anhui from 2001 to 2010 has a definite and obvious spatial distribution (Fig. 3). The significant geographical variations are characterized mainly by the transformation from crop/ natural vegetation mosaic to cropland in the middle region and from grassland to forest in the southwest and southeast.

Spatially, land cover and land use change have mainly occurred in the central region of the YangtzeHuaihe region and along the area of the Yangtze river in Anhui (Fig. 3). Some water body patches along the Yangtze and Huaihe were converted to wetlands during the 10-year period, with many scattered small low vegetation cover land patches in the central region of the study area converted to water bodies. The forest distribution in the southeast and southwest of Anhui expanded toward the fringes of grassland area and encroached on the grassland, causing the conversion from grassland to forest land. Conversion to forest is the main reason for the shrinkage of grassland, which was distributed mainly in the transitional zone where forest meets the grassland in the central area east of Dabie mountains and Huangshan mountains in Anhui. The spatial distribution of the conversion of wetlands was fragmented. The conversion of crop/natural vegetation mosaic to cropland was distributed mainly in the crop and natural vegetation interlaced zone in the central Yangtze-Huaihe region in the study area from 2001 to 2010. The conversion of grassland to cropland was distributed mainly in the crop and grass interlaced zone in the southwest and south-central region of Anhui.

The crop/natural vegetation mosaic in the central region shrunk obviously and transferred to cropland, while the forest in the southern region bordering the Dabie Mountains expanded toward the fringes of the grass area and encroached on the grassland, causing the conversion from grassland to forest (Figs 3c-d). The conversion from low vegetation cover land to water bodies took place mainly in the southern mountains over the study period. In general, the conversion of land use and land cover changes (LULCC) took place mainly in the central, southwestern and eastern regions of Anhui during the study period, compared to other regions. In addition, crop/natural vegetation mosaic land in the central area of Anhui was mainly converted into cropland and some grassland in the central area was converted into cropland. Influenced by a government policy of converting grassland into forest, many of these 
areas were converted into forest, although some forest was also converted into grassland and crop/ natural vegetation mosaic.

\section{Area Change of LUCC during the Study Periods}

Considerable changes occurred in land use/cover in the middle region of Anhui from 2001 to 2010, as shown in Fig. 4. The area covered by cropland, forest and wetlands greatly increased. The total area of cropland increased from $67999.30 \mathrm{~km}^{2}$ in 2001 to $88753.40 \mathrm{~km}^{2}$ in 2010 - an increase of $20754.10 \mathrm{~km}^{2}$ and $30.52 \%$ of the total cropland area in 2001 (Fig. 4a-b). The total forest area increased by $9438.00 \mathrm{~km}^{2}$, and $35.29 \%$ of the total forest area in 2001. The total wetlands area increased by $1198.88 \mathrm{~km}^{2}$ and 3.26 times of the area in 2001, with an annual growth rate of $32.60 \%$. The areas covered by water bodies and urban/built-up increased slightly during the 10 -year period. The annual rate of area increase in forest, cropland, water bodies and urban/ built-up reached $3.53 \%$ year $^{-1}, 3.05 \%$ year $^{-1}, 0.38 \%$ year $^{-1}$ and $0.09 \%$ year $^{-1}$ during 10 -year period.

On the contrary, areas covered by grassland, crop/ natural vegetation mosaic and low vegetation cover land decreased continuously from 2001 to 2010. The total crop/natural vegetation mosaic area decreased by $19699.04 \mathrm{~km}^{2}$ and $84.29 \%$ of the area in 2001, with a particularly dramatic decrease in the transition zone between hills and plains of central parts in the study

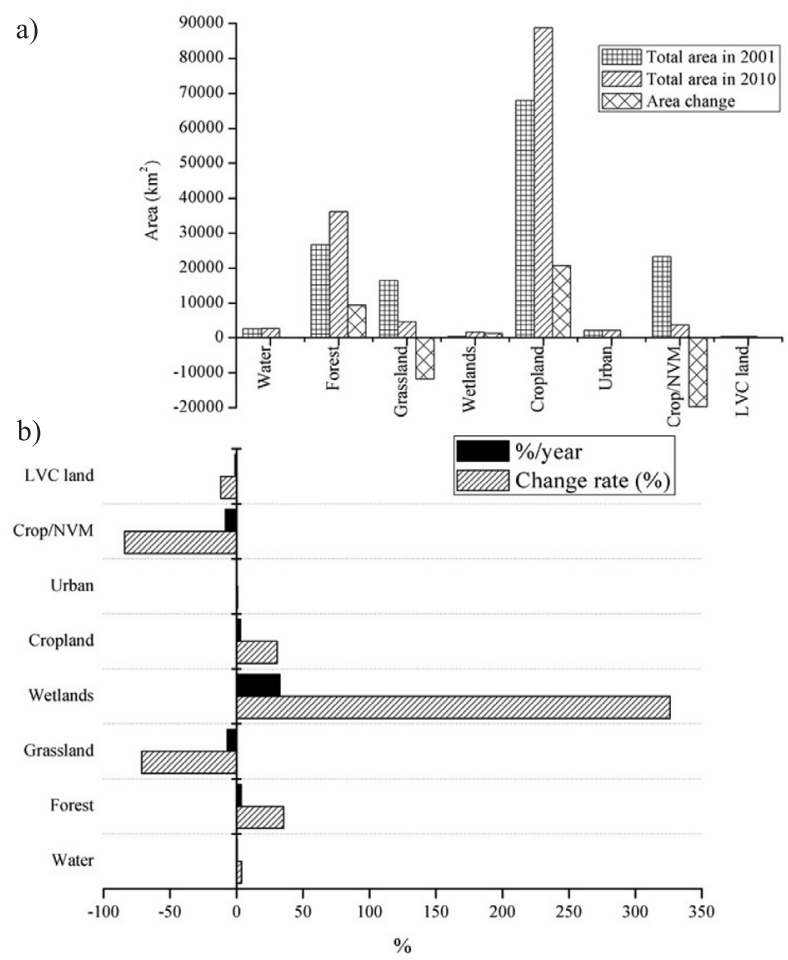

Fig. 4. Total area and area changes of different land use/cover types a) and change rates b) in Anhui from 2001 to 2010; crop/ NVM and LVC land present crop/natural vegetation mosaic and low vegetation cover land, respectively. area. The total area covered by grassland decreased by $11790.96 \mathrm{~km}^{2}$ and $71.32 \%$ of the area in 2001 , with an obvious decrease in the central and southern mountains, hills, within the transition zone between the mountains and plains. The total area covered by low vegetation cover land decreased by $45.50 \mathrm{~km}^{2}$, which is equivalent to $11.86 \%$ of the total area in 2001 during a 10 -year period. The annual rate of area decrease in grassland, crop and natural vegetation mosaic and low vegetation cover land reached $7.13 \%$ year $^{-1}, 8.43 \%$ year $^{-1}$ and $1.19 \%$ year $^{-1}$ from 2001 to 2010, respectively (Fig. 4b). The most notable changes in land use on Anhui were a decline in grassland and crop/natural vegetation mosaic and an increase in cropland and forest over the 10-year period.

\section{Transition Matrix Analysis of LUCC}

The land use transformation matrix demonstrates that the major land use changes occurred in this period, as shown in Table 1 and Fig. 5. Cropland comprises the largest portion of the total area at over $63.38 \%$ of the total area, which is located mainly in the center and northern part of Anhui. Compared to the other land cover types, the largest net increase area of cropland is $20754.10 \mathrm{~km}^{2}$, which is mainly attributed to a decrease in crop/natural vegetation mosaic and grassland areas. Approximately $17813.00 \mathrm{~km}^{2}(76.39 \%)$ of crop/ natural vegetation mosaic and $5850.63 \mathrm{~km}^{2}$ (35.46\%) of grasslands were converted into cropland during the 10 -year period. The newly reclaimed farmland was mainly located in the transition zone between the hills and plains. The total area of forest land increased significantly over the study period. The expansion in forest land mainly occurred at the expense of grassland; approximately $7385.31 \mathrm{~km}^{2}(44.76 \%)$ of grassland was converted into forest land. The increase in the forest land area was greatest in the areas of the southwestern and southern mountains. Areas of wetlands increased from 2001 to 2010, primarily because of the conversion of cropland, forest and grassland. During 2001 and 2010, the total areas of cropland, forest and grassland that were converted to wetlands were $417.13 \mathrm{~km}^{2}, 375.06 \mathrm{~km}^{2}$ and $331.13 \mathrm{~km}^{2}$, respectively. Water bodies had an increase of $97.94 \mathrm{~km}^{2}$ with drastic transformation with forest, low vegetation cover land and grassland. Meanwhile, urban/ built-up land had a slight increase, which mainly came from cropland and crop/natural vegetation mosaic.

Crop/natural vegetation mosaic land had a massive loss of $19699.04 \mathrm{~km}^{2}$, which was due mostly to conversion to cropland and forest, accounting for $76.39 \%$ and $14.45 \%$ of the total change area of crop/ natural vegetation mosaic, respectively. The total area of grassland decreased throughout the study period as grasslands were converted to forest and cropland. Between 2001 and 2010, approximately 44.76\% and $35.46 \%$ of the total grassland change area was converted to forest and cropland, respectively. The spatial extent of low vegetation cover land decreased between 2001 
Table 1. The dynamic transition matrix of land use/cover types between 2001 and $2010\left(\mathrm{~km}^{2}\right)$.

\begin{tabular}{|c|c|c|c|c|c|c|c|c|}
\hline \multirow{2}{*}{$\begin{array}{c}\text { Land-use types } \\
\text { in } 2001\end{array}$} & \multicolumn{7}{|c|}{ Land-use types in 2010} \\
\cline { 2 - 9 } & Unchanged & \multicolumn{7}{|c|}{ Changed-into } \\
\hline Water & Water & Forest & Grassland & Wetlands & Cropland & Urban & Crop/NVM & LVC land \\
\hline & 1928.94 & 207.69 & 68.63 & 146.81 & 100.69 & 0.63 & 13.00 & 77.00 \\
\hline Forest & Forest & Water & Grassland & Wetlands & Cropland & Urban & Crop/NVM & LVC land \\
\hline & 23029.60 & 326.00 & 1023.25 & 375.06 & 1325.69 & 35.44 & 435.00 & 103.19 \\
\hline Grassland & Grassland & Forest & Water & Wetlands & Cropland & Urban & Crop/NVM & LVC land \\
\hline & 1859.81 & 7385.31 & 88.88 & 331.13 & 5850.63 & 87.06 & 860.00 & 37.63 \\
\hline Wetlands & Wetlands & Forest & Grassland & Water & Cropland & Urban & Crop/NVM & LVC land \\
\hline & 60.88 & 92.56 & 33.81 & 70.63 & 85.06 & 1.19 & 9.63 & 11.69 \\
\hline Cropland & Cropland & Forest & Grassland & Wetlands & Water & Urban & Crop/NVM & LVC land \\
\hline & 62605.90 & 1883.31 & 919.88 & 417.13 & 59.44 & 602.56 & 1270.56 & 44.56 \\
\hline Urban & Urban & Forest & Grassland & Wetlands & Cropland & Water & Crop/NVM & LVC land \\
\hline & 1240.44 & 19.19 & 44.31 & 3.88 & 741.88 & 1.44 & 15.25 & 3.44 \\
\hline Crop/NVM & Crop/NVM & Forest & Grassland & Wetlands & Cropland & Urban & Water & LVC land \\
\hline & 1057.37 & 3368.88 & 747.13 & 166.69 & 17813.00 & 122.25 & 25.50 & 18.13 \\
\hline LVC land & LVC land & Forest & Grassland & Wetlands & Cropland & Urban & Crop/NVM & Water \\
\hline & 40.19 & 65.75 & 33.75 & 53.00 & 38.56 & 0.69 & 4.19 & 144.19 \\
\hline
\end{tabular}

Crop/NVM and LVC land present crop/natural vegetation mosaic and low vegetation cover land, respectively.

and 2010. Approximately $144.19 \mathrm{~km}^{2}, 65.75 \mathrm{~km}^{2}$ and $53 \mathrm{~km}^{2}$ of low vegetation cover land were transformed into water bodies, forest and wetlands, accounting for $37.91 \%, 17.29 \%$ and $13.94 \%$ of the total change area in low vegetation cover land over the study period, respectively (Table 1 and Fig. 5).

\section{Spatial Distribution of NPP Change}

Fig. 6 presents the spatial distribution of NPP throughout the study area in 2001 and 2010. NPP in most of the central area in 2001 ranged from 150 to $250 \mathrm{gC} \mathrm{m}^{-2}$. The peak values of vegetation NPP are

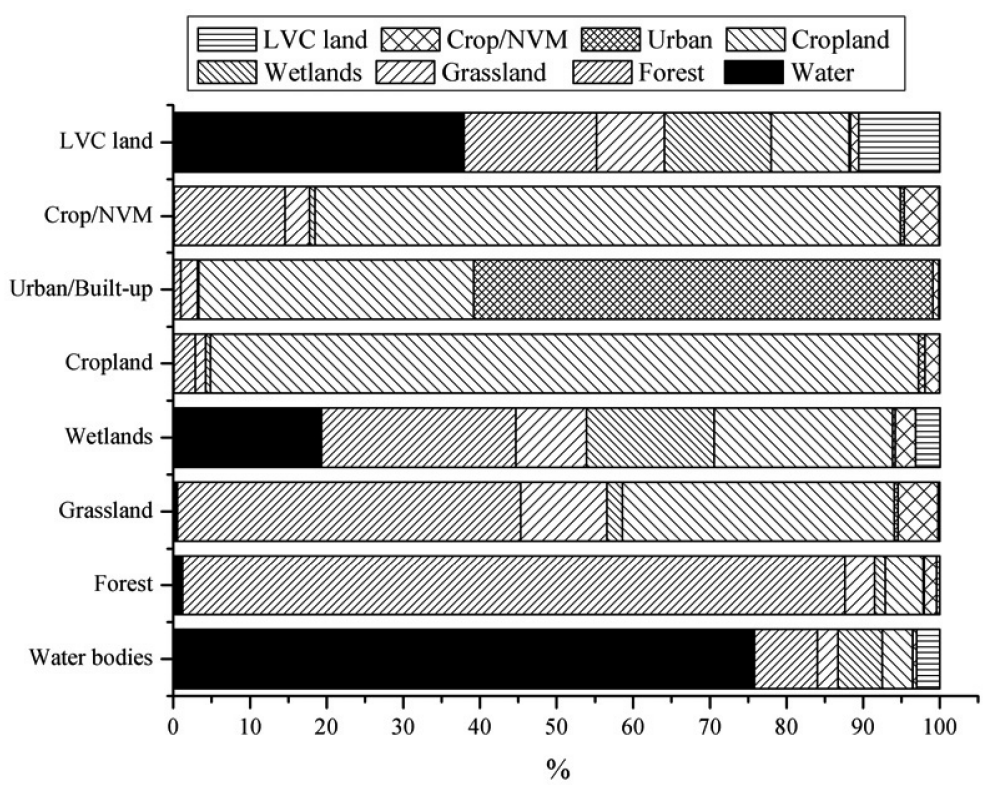

Fig. 5. Area percentages of different land use types of transferring matrix of LUCC in Anhui from 2001 to 2010. 


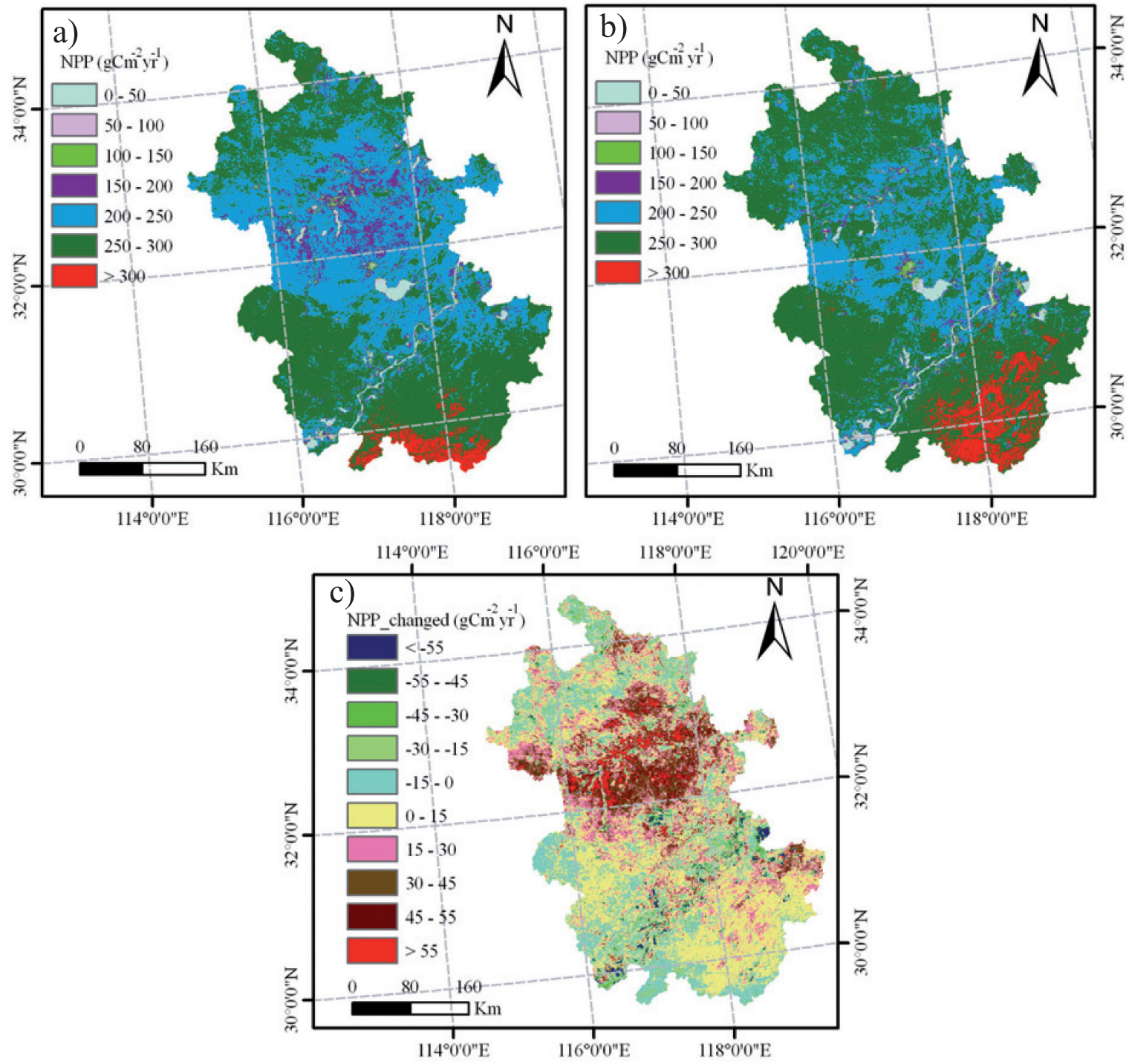

Fig. 6. Spatial distribution of NPP in Anhui province during 2001 a) and 2010 b), and NPP change c).

mainly distributed in southern mountains and hilly areas, where the NPP was highest $\left(>300 \mathrm{gC} \mathrm{m}^{-2}\right)$ in the total area, due to the distribution of a great amount of forest vegetation. Because of the abundance of arable land in the Yangtze-Huaihe plain, and because cropland NPP is lower than it is in the forest, the NPP value in the plain region was lower than in the mountains and hilly areas. The NPP of southern and southwestern areas mainly ranged from 250 to $300 \mathrm{gC} \mathrm{m}^{-2}$. During the 10 -year period, the NPP in some central areas had increased from the range of 150 to $250 \mathrm{gC} \mathrm{m}^{-2}$ into the range of 200 to $250 \mathrm{gC} \mathrm{m}^{-2}$ (Fig. 6).

The spatial conversion of land use and cover types in the southwestern and central parts of Anhui were more obvious than those that occurred elsewhere, and most conversions were observed between crop/natural vegetation mosaic and cropland, which mainly occurred in Yangtz-Huaihe plain and along the Yangtze River. Meanwhile, most conversions from grassland to forest were also found in the near southwest side of the Dabie Mountains in southwestern Anhui. The spatial changes of NPP in Anhui from 2001 to 2010 as a result of these conversions are shown in Fig. 6c). NPP in the central region of the Yangtze-Huaihe plain increased obviously during the 10-year period, with the variation value increased from 45 to $55 \mathrm{gC} \mathrm{m}^{-2}$, however, NPP in the southwestern and northeastern region of Anhui had partly decreased with the variation NPP value from 0 to $30 \mathrm{gC} \mathrm{m}^{-2}$ (Fig. 6c). The natural vegetation along with the area of the Yangtze has a decreased NPP value, whereas the majority of the cultivated and forest vegetation area in the south and central region have increased by $0-15 \mathrm{gC} \mathrm{m}^{-2} \mathrm{NPP}$ values from 2001 to 2010. Compared with 2001, NPP in the north of the study region decreased by $15-30 \mathrm{gC} \mathrm{m}^{-2}$ in 2010 . In some fractional areas of eastern Anhui, NPP had an obvious reduction of 45-55 $\mathrm{gC} \mathrm{m}^{-2}$. In general, vegetation with an NPP increase was most widely distributed in the central plain, and southern and southwestern mountains of Anhui, but the decreased NPP mainly occurred in scattered areas of the study region. 
Table 2. Mean and total NPP and NPP change of different vegetation cover types in 2001 and 2010 in Anhui.

\begin{tabular}{|c|c|c|c|c|c|c|c|c|}
\hline Land cover & \multicolumn{2}{|c|}{ Mean NPP $\left(\mathrm{g} \mathrm{Cm}^{-2} \mathrm{yr}^{-1}\right)$} & Unit change & Percent change & \multicolumn{2}{|c|}{ Total NPP $(\mathrm{Gg} \mathrm{C})$} & Total change & Percent change \\
\hline & 2001 & 2010 & $\left(\mathrm{~g} \mathrm{Cm}^{-2}\right)$ & $(\%)$ & 2001 & 2010 & $(\mathrm{Gg} \mathrm{C})$ & $(\%)$ \\
\hline Forest & 278.87 & 283.60 & 4.74 & 1.70 & 7408.06 & 10209.69 & 2801.63 & 37.82 \\
\hline Grassland & 257.76 & 252.29 & -5.47 & -2.12 & 4246.10 & 1191.21 & -3054.89 & -71.95 \\
\hline Wetlands & 192.45 & 209.28 & 16.83 & 8.75 & 70.10 & 324.47 & 254.37 & 362.86 \\
\hline Cropland & 237.54 & 249.33 & 11.79 & 4.96 & 16075.38 & 22053.63 & 5978.25 & 37.19 \\
\hline Crop/NVM & 238.71 & 260.84 & 22.13 & 9.27 & 5557.92 & 954.86 & -4603.06 & -82.82 \\
\hline LVC land & 117.33 & 110.43 & -6.90 & -5.88 & 44.53 & 37.04 & -7.49 & -16.82 \\
\hline Total & 247.90 & 258.10 & 10.19 & 4.11 & 33402.08 & 34770.88 & 1368.80 & 4.10 \\
\hline
\end{tabular}

\section{Impacts of LUCC on NPP Change during Study Periods}

Estimated value of mean and total NPP and percentage change in 2001 and 2010 for Anhui are shown in Table 2. The land covers related to vegetation have been shown, while non-vegetation cover types have not been included in the study. Mean NPP for the study area was $247.90 \mathrm{~g} \mathrm{Cm}^{-2}$ in 2001 and $258.10 \mathrm{~g} \mathrm{Cm}^{-2}$ in 2010. The largest mean NPP gain (22.13 $\mathrm{g} \mathrm{Cm}^{-2}$ ) occurred in crop/natural vegetation mosaic areas and increased by $9.27 \%$ from 2001 to 2010 . The mean NPP in wetlands and grassland have also increased by 16.83 (9.27\%) and $11.79 \mathrm{~g} \mathrm{Cm}^{-2}$ (4.96\%) compared to that in 2001. Meanwhile, the mean NPP in forest has gained $4.74 \mathrm{~g} \mathrm{Cm}^{-2}$ over the study period. However, the largest NPP loss $\left(6.90 \mathrm{~g} \mathrm{Cm}^{-2}\right)$ was found in low vegetation cover land areas during a 10-year period. NPP loss in grassland areas was $5.47 \mathrm{~g} \mathrm{Cm}^{-2}$. During the 10-year period, mean NPP for the total area decreased from 247.90 to $258.10 \mathrm{~g} \mathrm{Cm}^{-2}$. Among all land cover types, mean NPP of low vegetation cover land had exhibited the most decrease, about 5.88\%, while grassland decreased about $3.6 \%$.

It is shown that total NPP for Anhui increased from 2001 to 2010 in cropland, forest, wetlands and whole area, while those of grassland, crop/natural vegetation mosaic and low vegetation cover land all decreased during the study period (Table 2). Total NPP of the whole region increased from 33402.08 to $34770.88 \mathrm{GgC}$ during the 10 -year period, which increased by $1368.80 \mathrm{GgC}$ or $4.10 \%$ compared to that in 2001, in which cropland and forest NPP played a major role in the increase due to the area increases of 20754.10 and $9438.00 \mathrm{~km}^{2}$, respectively. Because of the area decrease of $19699.04 \mathrm{~km}^{2}$, although mean NPP of crop/natural vegetation mosaic increased by $22.13 \mathrm{gC} \mathrm{m}^{-2}$, total NPP decreased by $4603.06 \mathrm{GgC}$ over the 10 -year period. As the grassland area shrank, total grassland NPP decreased by $3054.89 \mathrm{GgC}$, mostly due to the area reduction of grassland by $11790.96 \mathrm{~km}^{2}$, and the decrease of mean NPP in grassland also contributed to the reduction of total grassland NPP. Total NPP of low vegetation cover land decreased slightly during the 10 -year period.

In contrast, total wetland NPP increased by 254.37 $\mathrm{GgC}$ - mostly due to the area expansion of wetlands by $1198.88 \mathrm{~km}^{2}$, meanwhile the increased mean NPP promoted the increase of the total NPP. The largest change value in total NPP was observed for cropland, with an increase of 5978.25, which was $37.19 \%$ of the total cropland NPP in 2001. As the most significant increase of percentage change in total NPP, the total wetland NPP increased from 70.10 in 2001 to $324.47 \mathrm{GgC}$ in 2010 , with an increase of $254.37 \mathrm{GgC}$, which was $362.86 \%$ of the total wetland NPP in 2001. Total forest NPP had increased from $7408.06 \mathrm{GgC}$ to $10209.69 \mathrm{GgC}$ and gained $2801.63 \mathrm{GgC}$ - mainly due to the expansion of the forest area by $9438.00 \mathrm{~km}^{2}$ during the study period.

The mean NPP and total NPP of different vegetation types for unchanged land use and land cover areas were observed during the study period (Table 3). As shown in Table 3, during the 10-year period, mean NPP in unchanged cropland had the most obvious increase with an increase of $13.51 \mathrm{~g} \mathrm{Cm}^{-2}$, compared to that of other vegetation types. Mean NPP in unchanged forest,

Table 3. The change of mean and total NPP in the unchanged vegetation types during 2001-2010.

\begin{tabular}{|c|c|c|}
\hline Unchanged vegetation types & $\begin{array}{c}\text { Mean NPP } \\
\text { change }\end{array}$ & $\begin{array}{c}\text { Total NPP } \\
\text { change }\end{array}$ \\
\cline { 2 - 3 } & $\left(\mathrm{g} \mathrm{Cm}^{-2}\right)$ & $(\mathrm{Gg} \mathrm{C})$ \\
\hline Forest & 2.84 & 71.25 \\
\hline Grassland & 1.36 & 2.70 \\
\hline Wetlands & -3.37 & -0.20 \\
\hline Cropland & 13.51 & 851.50 \\
\hline Crop/NVM & 5.63 & 6.18 \\
\hline LVC land & -0.25 & -0.01 \\
\hline
\end{tabular}

$\mathrm{Crop} / \mathrm{NVM}$ and LVC land present crop/natural vegetation mosaic and low vegetation cover land, respectively. 
grassland and crop/natural vegetation mosaic had also increased by $2.84,1.36$ and $5.63 \mathrm{~g} \mathrm{Cm}^{-2}$, respectively. In contrast, mean NPP of unchanged wetlands had obviously decreased with a loss of $3.37 \mathrm{~g} \mathrm{Cm}^{-2}$ from 2001 to 2010. Additionally, mean NPP of unchanged low vegetation cover land exhibited marginal decrease with a reduction of $0.25 \mathrm{~g} \mathrm{Cm}^{-2}$ (Table 3). Total NPP in unchanged cropland showed the most increase of 851.5 Gg C, while total NPP of unchanged wetlands and low vegetation cover land decreased by 0.20 and 0.01 Gg C, respectively (Table 3 ). During the 10 -year period, total NPP of unchanged forest increased considerably in the study period, in which the total NPP increased by $71.25 \mathrm{Gg}$ C. The total NPP of unchanged grassland and crop/natural vegetation mosaic increased slightly during the 10 -year period.

\section{Discussion}

\section{Influencing Factors of Land Use and Land Cover Change}

Human activities have been regarded as an important driving factor of the land use/cover change [35]. The above analysis reveals that cropland significantly expanded and crop/natural vegetation mosaic shrunk obviously between 2001 and 2010, which mainly concerned human activities. Fig. 3 shows an example of this phenomenon. Land use/cover change is often correlated with the implementation of national policy [35], which has been considered a major factor of land use/cover change [36]. Over the past 60 years, Anhui has always been defined as a major agricultural province and grain-producing area, where its agricultural production accounts for an important part of the province's output value. Recently, a price increase for agricultural products has led farmers to plant crops on cropland that had been converted from other cover types or to reclaim new farmland. The impact of these polices and socio-economic factors on the expansion of farmland are obvious and have resulted in a dramatic increase of cropland over the 10-year period. Specifically, the implementation of nation policy mainly affected the evolution of patterns of land use/cover in the central areas of the interlaced zone between cropland and crop/ natural vegetation mosaic.

With the implementation of the cropland protection policy in China, the development on cropland has been limited and existing cropland has been preserved as much as possible. The strong willingness to pursue economic interests significantly affected the land use/cover change. After 2001, socio-economic development proceeded very rapidly in Anhui. In 2001, the GDP was 324.67 billion CNY. In 2010, the GDP reached 1235.93 billion CNY. Fig. 7 shows GDP a), grain yield b) and population c) of Anhui from 2001 to 2010. The average annual growth rate of the GDP between 2001and 2010 was approximately $16.11 \%$ (Fig. 7a). The utilization of expanded cropland to grow
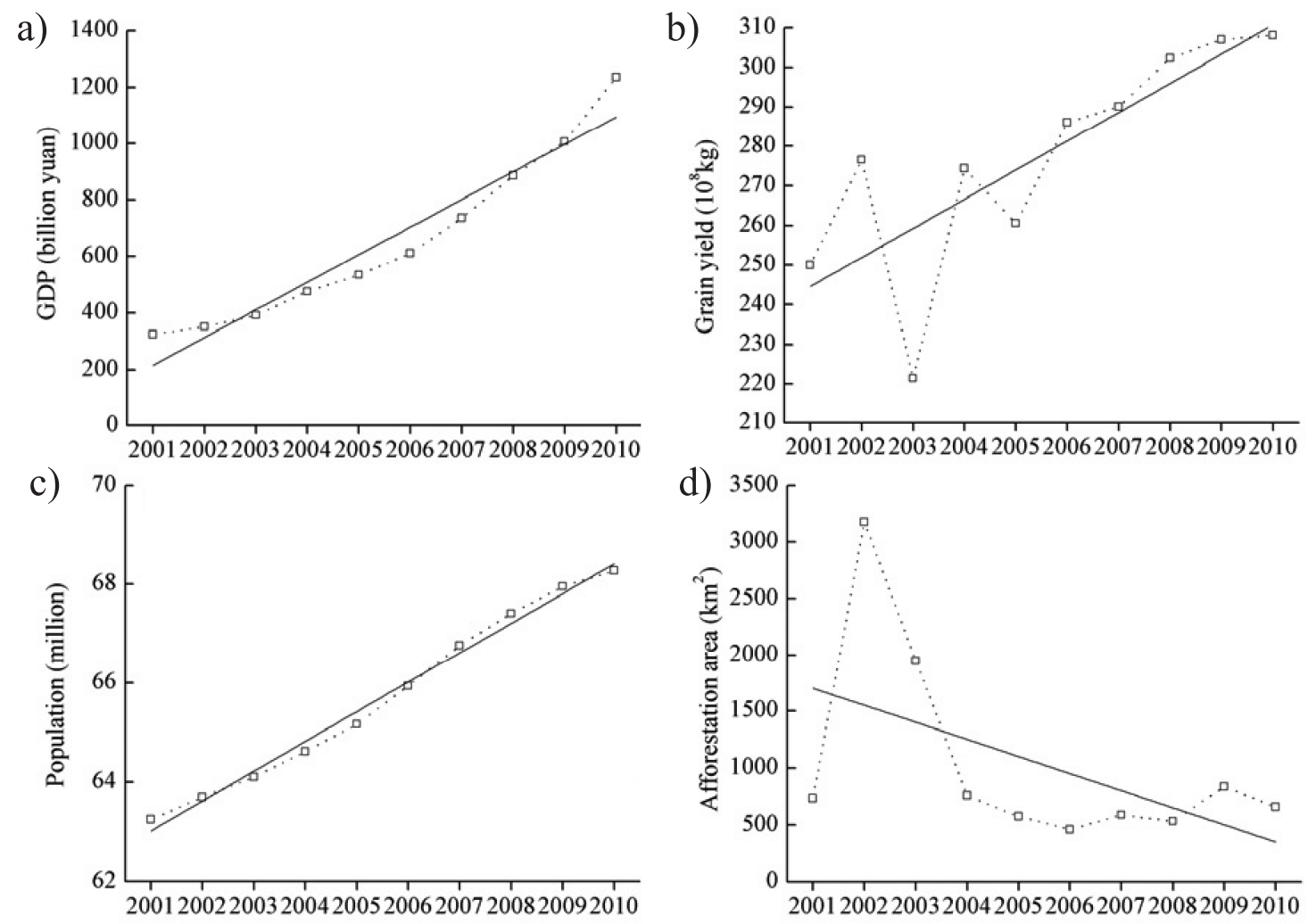

Fig. 7. GDP (gross domestic product) a), grain yield b), population c) and afforestation area d) of Anhui from 2001 to 2010. 
crops significantly increased grain yield. In 2010, the grain yield of Anhui reached $308.05 \times 10^{8} \mathrm{~kg}$, increasing by $23.21 \%$ compared to that in 2001 (Fig. 7b). Just like other parts of central-eastern China, crop production has still played the most important role in the local peoples' lives, which was therefore a significant factor in the cropland expansion in the study area. This finding was similar to the research result of land use/cover change in Sanjiang Plain, China [19].

For pursuing their income and supporting a growing rural population, the local people tried to expand cropland and pond with higher economic benefits, which contributed to the expansion of water bodies. The development of socio-economic conditions also spurred the expansion of urban/built-up land. From 2001 to 2010, the area of urban/built-up land increased by $0.87 \%$. As an important factor affecting land use/cover change, the population in Anhui increased obviously, with an increase of 5.02 million from 2001 to 2010 (Fig. 7c). With the development of population, the human disturbance intensified dramatically. Over the 10 -year period, the crop/natural vegetation mosaic and grassland area exhibited an evident shrinkage mainly due to the expansion of cropland caused by human appropriation. As an agricultural province in central China, crop planting occupied a dominant part of agricultural production in Anhui compared to animal husbandry, which mainly contributed to the expansion of cropland and the shrinkage of natural vegetation mosaic and grassland.

In recently years China's government has invested huge amounts of money to implement a series of Key Forestry Programs (KFP) for alleviating severe land degradation problems and improving the ecological environment [37]. China has invested 725 billion $\mathrm{RMB}$ in these programs, covering more than $97 \%$ of China's counties for afforestation from 2001 to 2009 [37]. These afforestation policies, such as the Forest Industrial Base Development Program (FIBDP) were also continuously implemented in the southern and southwestern mountains of Anhui. In those areas, the afforestation policies had an evident positive effect on the proportion of the forest landscapes. Over the 10-year period, the total afforestation area of Anhui reached $10260 \mathrm{~km}^{2}$ [38], in which the annual afforestation area in 2002 had reached the peak value $\left(3177.1 \mathrm{~km}^{2}\right)$ and then exhibited a downward trend (Fig 7d). However, the accumulated afforestation area has gradually increased over the 10-year period. After the implementation of the afforestation policies, the forest area in the study area increased by $35.29 \%$ from 2001 to 2010 . Other projects (e.g., Wildlife Conservation and Nature Reserves Protection Program) also influenced land use/ cover change in Anhui. The Wildlife Conservation and Nature Reserves Protection Program (WCNR) strive to expand the number of nature reserves and enhance the protection of wildlife, in which wetland restoration has been taken as an important aspect. It proposes that the total number of reserves reach 1,800 by 2010 and 2,000 by 2030 [39]. The evident increase in the wetland area can be explained by the implementation of the WCNR in the study area, which resulted in an overall increase in wetland areas over the 10 -year period.

Thus, remarkable expansion of cropland, forest and wetland, slight expansion of water bodies and urban/build-up, and evident shrinking of crop/natural vegetation mosaic and grassland are the characteristics of land use/cover change in the study area over 10 years. Rapid expansion of cropland and built-up land and evident shrinkage of natural vegetation also occurred in other areas (Guangdong, Gansu and Shanxi) in China due to the improvement of socioeconomic conditions and population growth [15, 23]. Agricultural expansion was also found in the ecologically fragile and economically underdeveloped areas in western China. In temperate South America, conversion of grasslands into croplands resulted from the aptitude of their soils and the adequate climatic conditions; however, driven by technological changes and market circumstances, the rate of agricultural expansion has increased considerably [40].

\section{Influence of Land Use and Land Cover Changes on NPP}

Land use and land cover change (LUCC) has important impacts on net primary production (NPP) in terrestrial ecosystems [19]. However, NPP is usually influenced by not only LUCC but also climate change [20], so it becomes important to distinguish the relative contribution on NPP between the two driving factors. In this study, we designed one scenario of simulation to understand the effects of LUCC and climate change on NPP in Anhui from 2001 to 2010. The scenario allowed NDVI to change, while all climatic factors (radiation, precipitation and temperature) remained in 2001. This scenario allowed for the change of stable classes in NDVI; however, some of the changes might be caused by climate change. We assumed that the meteorological conditions in 2001 remain unchanged into 2010, that is, use the climatic parameters in 2001 to simulate the NPP of Anhui in 2010 (Total NPP 2010 scenario). The difference between (Total NPP 2010 scenario $)$ and Total $\mathrm{NPP}_{2010} /$ Total $\mathrm{NPP}_{2001}$ were used to understand the relative roles of climate change and LUCC over the 10-year period (Table 4). Table 4 shows that the difference between total $\mathrm{NPP}_{2010}$ and total $\mathrm{NPP}_{2010 \text { scenario }}$ was $-449.84 \mathrm{Gg} \mathrm{C}$, which means climate change had a negative effect on NPP during the study period. However, the difference between total $\mathrm{NPP}_{2010 \text { scenario }}$ and total $\mathrm{NPP}_{2001}$ was 1816.05 $\mathrm{GgC}$, which means LUCC had a positive effect on NPP and spurred the increase of NPP during the decade. The total NPP was $35381.93 \mathrm{GgC}$ in 2010 and increased by 1366.21 GgC, compared to that in 2001 (Table 4), which means that the combined role of climate change and LUCC led to the increase of NPP during the 10-year period. Thus, both climate change and LUCC had an impact on NPP where LUCC contributed to the increase 
Table 4. Total NPP change induced by climate change and LUCC in Anhui from 2001 to 2010.

\begin{tabular}{|c|c|c|}
\hline & Total $\mathrm{NPP}_{\text {changed }}(\mathrm{Gg} \mathrm{C})$ & Description \\
\hline Total $\mathrm{NPP}_{2010}-$ Total $\mathrm{NPP}_{2010 \_ \text {_cenario }}$ & -449.84 & Climate change induced \\
\hline Total $\mathrm{NPP}_{2010 \_ \text {scenario }}-$ Total NPP ${ }_{2001}$ & 1816.05 & LUCC induced \\
\hline Total $\mathrm{NPP}_{2010}-$ Total NPP & 1366.21 & Both climate change and LUCC induced \\
\hline
\end{tabular}

of NPP, however, climate change partly counteracted the increase of NPP during the 10-year period. LUCC resulted in the increase of NPP with $1816.05 \mathrm{GgC}$, while climate change brought in an adverse effect and caused the reduction of NPP with $449.84 \mathrm{GgC}$ over the study period. Ultimately, the total NPP of Anhui just increased by $1366.21 \mathrm{GgC}$ during the 10 -year period (Table 4).

LUCC and climate change have interactive effects on terrestrial productivity, which usually results in the mixed manifestations of these two forces [41]. How to decouple the effects of LUCC and climate change on NPP is challenging. In this study, we examined the short-term NPP change caused by fast LUCC and climate change. The results demonstrated that LUCC and climate change exhibited very different impacts on NPP in Anhui (Table 4). It is difficult to accurately understand that the relative contribution of LUCC and climate change on NPP under combining that together in the study area. Additionally, as the climate influences the biophysical characteristics of LUCC, it is also impossible to completely distinguish the effects of LUCC and climate change on NPP. In our study, we have cleared that climate change reduced NPP despite an overall increase in NPP in Anhui, and provided insight into the quantitative contribution of LUCC and climate change effects on NPP.

In our study, we also have compared the changes of the mean and total NPP in the regions where LUCC did not occur from 2001 to 2010. Both the mean and total NPP of unchanged and whole forest all have increased in Anhui over the 10-year period, which suggested that the contribution of forest protection and reforestation to the increase in NPP is extremely remarkable, indicating that forest quality per area improved from 2001 to 2010. As similar with forest, both mean NPP and total NPP of cropland have increased in both whole cropland and unchanged cropland, respectively (Table 2 and Table 3), indicating that the expansion of cropland area and the improvement of cropland qualities that have occurred in Anhui may be due to agricultural investment. However, the mean and total NPP of whole grassland decreased (Table 2) in spite of its increase in unchanged grassland (Table 3), which suggested that slight degradation of grassland has occurred in newly developing grassland at the research regions, while grassland restoration has been found in unchanged grassland from 2001 to 2010. For wetlands, despite the increase of the mean and total NPP in whole wetlands area, that in unchanged wetlands exhibited a downward trend, indicating that wetland qualities per area deteriorated from 2001 to
2010. Although the mean and total NPP in unchanged crop/natural vegetation mosaic increased slightly (Table 3), the total NPP in whole crop/natural vegetation mosaic land experienced a huge loss of 4603.06 GgC due to the shrinkage of the area (Table 2). The mean and total NPP of low vegetation cover land had a slight reduction for the unchanged and the whole low vegetation cover land during the study period, respectively (Tables 2-3), which indicates that besides the area shrinkage of whole low vegetation cover land, the cover type also experienced slight deterioration over the 10 -year period in unchanged low vegetation cover regions.

As mentioned above, wetland conditions of unchanged wetlands have deteriorated during the decade, which has damaged the natural vegetation and resulted in decreasing NPP values in unchanged wetlands. So improved management practices in the unchanged areas, such as forbidding grazing on grassland, protection of water quality in wetlands and vegetation restoration in low vegetation cover land, are still important. In our study, we found that reforestation and forest protection could significantly enhance ecosystem productivity and offset the negative impacts from climate change on NPP across Anhui. Reforestation and forest protection had led to a net NPP increase up to $2801.63 \mathrm{Gg}$ C in Anhui during 2001-2010 (Table 2). With the implementation of ecological restoration programs, a greater carbon sequestration capacity has been expected in Anhui if these new forests are properly managed in the future.

\section{Conclusions}

In this paper, we investigated changes in land use and land cover in Anhui between 2001 and 2010, discussed the driving factors of LUCC, and explored the impacts of LUCC on NPP in Anhui from 2001 to 2010. Land use and land cover has changed significantly in Anhui, where the area of land use and cover change accounted for approximately $34.25 \%$ of the whole area over the 10-year period. Areas of cropland, forest and wetlands significantly increased, in which cropland had the most increase, compared to other land use and cover types. In contrast, the areas occupied by crop/natural vegetation mosaic and grassland considerably decreased during the 10 -year period, which decreased by $84.29 \%$ and $71.32 \%$ between 2001 and 2010, respectively. The most dominant land use and cover change in Anhui over 2000-2010 were the conversions from grassland 
and crop/natural vegetation mosaic to forest and cropland, as well as mutual transformation between other types. The continuous expansion of cropland and forest mainly resulted from economic interests and government policies. From 2001 to 2010, cropland and forest areas increased by $30.52 \%$ and $35.29 \%$, respectively.

The estimated total NPP for Anhui was 33402.08 in 2001 and $34770.88 \mathrm{GgC}$ in 2010. Total NPP of the whole area increased by $1368.80 \mathrm{GgC}$ mainly due to the contributions of increased NPP in cropland and forest over the study period. According to scenario analyses, both LUCC and climate change exhibited noticeable impacts on the NPP. LUCC in the study region, particularly the increase of forest area, resulted from reforestation and forest protection, significantly increasing the regional NPP. Climate change generally reduced the NPP of $449.84 \mathrm{GgC}$ during the 10 -year period. However, the factor of LUCC facilitated the NPP, which resulted in an increase of $1816.05 \mathrm{GgC}$. Colligating the climate and human factors, they synthetically led to a total NPP increase of $1366.21 \mathrm{GgC}$ during the study period. This indicates that the NPP increase induced by LUCC could offset the NPP decrease from climate change in the whole study region. Our results found that unchanged wetland qualities per area deteriorated from 2001 to 2010. Wetland quality protection is necessary in future periods. Our study also demonstrated that reforestation and forest protection were indeed effective in promoting ecosystem productivity, partly mitigating global warming and increasing carbon sequestration. The methodology and synthesized analysis developed in this study can be ultilized in other regions to evaluate the driving effects of LUCC and climate change on ecosystem NPP.

\section{Acknowledgements}

We are grateful to the chief editor and anonymous reviewers for their illuminating comments. This research was mainly supported by the Natural Science Foundation of Anhui Province (grant No.1508085QC68), the Natural Science Research Key Project in College of Anhui Province (grant No. KJ2015A127), the Research Culture Funds of Anhui Normal University (2013rcpy40), the Foundation of Collaborative Innovation Center of Recovery and Reconstruction of Degraded Ecosystem in Wanjiang City Belt (Anhui Province), the Foundation of Provincial Key Laboratory of Conservation and Utilization for Important Biological Resource in Anhui, and the Foundation of Key Laboratory Biot Environment and Ecological Safety of Anhui Province.

\section{Conflict of Interest}

The authors declare no conflict of interest.

\section{References}

1. GIRI C., PENGRA B., LONG J., LOVELAND T.R. Next generation of global land cover characterization, mapping, and monitoring. Int J Appl Earth Obs. 25, 30, 2013.

2. ZHAO W., HU Z., LI S., GUO Q., LIU Z., ZHANG L. Comparison of surface energy budgets and feedbacks to microclimate among different land use types in an agropastoral ecotone of northern china. Sci Total Environ. s 599-600, 891, 2017.

3. BONILLA-BEDOYA S., LÓPEZ-ULLOA M., VANWALLEGHEM T., HERRERA-MACHUCA M. Effects of land use change on soil quality indicators in forest landscapes of the western amazon. Soil Sci. 182, 128, 2017.

4. DE BAAN L., ALKEMADE R., KOELLNER T. Land use impacts on biodiversity in LCA: a global approach. Int $\mathrm{J}$ Life Cycle Assess. 18, 1216, 2013.

5. LU X., ZHOU Y., LIU Y., YANNICK L.P. The role of protected areas in land use/land cover change and the carbon cycle in the conterminous united states. Global Chang Biol. 24, 617, 2018.

6. PERRING M.P., DE F.P., BAETEN L., MAES S.L., DEPAUW L., BLONDEEL H., CARÓN M.M., Verheyen K. Global environmental change effects on ecosystems: the importance of land-use legacies. Global Change Biol. 22, 1361, 2016.

7. II B.L.T. Local faces, global flows: The role of land use and land cover in global environmental change. Land Degrad Dev. 5, 71, 2010.

8. VITOUSEK P.M., MOONEY H.A., LUBCHENCO J. MELILLO J.M. Human domination of Earth's ecosystems. Science. 277, 494, 1997.

9. LIU Y., YANG R., LONG H., GAO J., WANG J. Implications of land-use change in rural china: a case study of Yucheng, Shandong province. Land Use Policy. 40, 111, 2014.

10. YIN R.S., XU J.T., LI Z., LIU C. China's ecological rehabilitation: the unprecedented efforts and dramatic impacts of reforestation and slope protection in Western China. China Environment Series. 6, 17, 2005.

11. LIU D., CHEN Y., CAI W., DONG W.J., XIAO J.F., CHEN J.Q., ZHANG H.C., XIA J.Z., YUAN W.P. The contribution of China's Grain to Green Program to carbon sequestration. Landscape Ecol. 29, 1675, 2014.

12. ZHAO M., RUNNING S.W. Drought-induced reduction in global terrestrial net primary production from 2000 through 2009. Science. 329, 940, 2010.

13. SONG C., DANNENBERG M.P., HWANG T. Optical remote sensing of terrestrial ecosystem primary productivity. Prog Phys Geogr. 37, 834, 2013.

14. SOHL T.L., SLEETER B.M., ZHU Z., SAYLER K.L., BENNETT S., BOUCHARD M., REKER R., HAWBAKER T., WEIN A., LIU S., KANENGIETER R., ACEVEDO W. A land-use and land-cover modeling strategy to support a national assessment of carbon stocks and fluxes. Appl Geogr. 34, 111, 2012.

15. CHUAI X.W., HUANG X.J., ZHENG Z.Q., ZHANG M., LIAO Q.L., LAI L., LU J.Y. Land Use Change and Its Influence on Carbon Storage of Terrestrial Ecosystems in Jiangsu Province. Resources Science. 33, 1932, 2011 [In Chinese].

16. BREUNING-MADSEN H., KRISTENSEN J.A., HOLST M.K., Balstroem T., Henriksen P.S. A comparison of soil organic carbon stocks in Viking Age and modern land 
use systems in Denmark. Agr Ecosyst Environ. 174, 49, 2013.

17. OGLE S.M., OLANDER L., WOLLENBERG L., ROSENSTOCK T., TUBIELLO F., PAUSTIAN K., BUENDIA L., NIHART A., SMITH P. Reducing greenhouse gas emissions and adapting agricultural management for climate change in developing countries: providing the basis for action. Global Change Biol. 20, 1, 2014.

18. POTTER C.S., RANDERSON J.T., FIELD C.B., MATSON P.A., VITOUSEK P.M., MOONEY H.A., KLOOSTER S.A. Terrestrial ecosystem production: a process model based on global satellite and surface data. Global Biogeochem Cycles. 7, 811, 1993.

19. DONG G., BAI J., YANG S., WU L., CAI M., ZHANG Y., LUO Y., WANG Z. The impact of land use and land cover change on net primary productivity on China's Sanjiang Plain. Environ Earth Sci. 74, 2907, 2015.

20. ZHANG Y.L., SONG C.H., ZHANG K.R., CHENG X.L., BANG L., ZHANG Q.F. Effects of land use/land cover and climate changes on terrestrial net primary productivity in the Yangtze River Basin, China, from 2001 to 2010. J Geophys Res: Biogeosciences. 119, 1092, 2014.

21. LU D.S., XU X.F., TIAN H.Q., MORAN E., ZHAO M.S., RUNNING S. The effects of urbanization on net primary productivity in southeastern China. Environ Manag. 46, 404, 2010.

22. REN Y., WEI X., WEI X.H., PAN J.Z., XIE P.P., SONG X.D., PENG D., ZHAO J.Z. Relationship between vegetation carbon storage and urbanization: a case study of Xiamen, China. For Ecol Manag. 261, 1214, 2011.

23. PEI F.S., LI X., LIU X.P., LAO C.H., XIA G.R. Exploring the response of net primary productivity variations to urban expansion and climate change: A scenario analysis for Guangdong Province in China. J Environ Manage. 150, 92, 2015.

24. CHEN B., ZHANG X., TAO J., WU J.S., WANG J.S., SHI P.L., ZHANG Y.J., YU C.Q. The impact of climate change and anthropogenic activities on alpine grassland over the Qinghai-Tibet Plateau. Agr Forest Meteorol. 189-190, 11, 2014.

25. PAN Y., YU C., ZHANG X., CHEN B., WU J., TU Y., MIAO Y., LUO L. A modified framework for the regional assessment of climate and human impacts on net primary productivity. Ecol Indic. 60, 184, 2016.

26. PIAO S., SITCH S., CIAIS P., FRIEDLINGSTEIN P., PEYLIN P., WANG X., AHLSTRÖM A., ANAV A., CANADELL J.G., CONG N., HUNTINGFORD C., JUNG M., LEVIS S., LEVY P.E., LI J., LIN X., LOMAS M.R., LU M., LUO Y., MA Y., MYNENI R.B., POULTER B., SUN Z., WANG T., VIOVY N., ZAEHLE S., ZENG N. Evaluation of terrestrial carbon cycle models for their response to climate variability and to $\mathrm{CO}_{2}$, trends. Global Change Biol. 19, 2117, 2013.

27. ZHOU W, YANG H, HUANG L, CHEN C., LIN X., HU Z., LI J. Grassland degradation remote sensing monitoring and driving factors quantitative assessment in China from 1982 to 2010. Ecol Indic. 83, 303, 2017.
28. JAHELNABI A E, ZHAO J, LI C H, FADOUL S.M., SHI Y.F., BSHEER A.K., YAGOUB Y.E. Assessment of the contribution of climate change and human activities to desertification in Northern Kordofan-Province, Sudan using net primary productivity as an indicator. Contemp Probl Ecol. 9, 674, 2016.

29. FOLEY J.A., DEFRIES R., ASNER G.P., BARFORD C., BONAN G. Global consequences of land use. Science. 309, 570, 2005.

30. ZHANG M., HUANG X., CHUAI X., YANG H., LAI L., TAN J. Impact of land use type conversion on carbon storage in terrestrial ecosystems of china: a spatialtemporal perspective. Sci Rep. 5, 10233, 2015.

31. RUIMY A., SAUGIER B. Methodology for the estimation of terrestrial net primary production from remotely sensed data. J Geophys Res. 97, 18515, 1994.

32. FIELD C.B., RANDERSON J.T., MALMSTRÖM C.M. Global net primary production: combining ecology and remote sensing. Remote Sens Environ. 51, 74, 1995.

33. ZHU W.Q., PAN Y.Z., ZHANG J.S. Estimation of net primary productivity of Chinese terrestrial vegetation based on remote sensing. Acta Phytoecol Sin. 31, 413, 2007.

34. POTTER C., KLOOSTER S., MYNENI R., GENOVESE V., TAN P.N., KUMAR V. Continental-scale comparisons of terrestrial carbon sinks estimated from satellite data and ecosystem modeling 1982-1998. Global Planet Change. 39, 201, 2003.

35. LI Y., LIU G. Characterizing Spatiotemporal Pattern of Land Use Change and Its Driving Force Based on GIS and Landscape Analysis Techniques in Tianjin during 20002015. Sustainability, 9, 894, 2017.

36. ZHOU D.C., ZHAO S.Q., ZHU C. The Grain for Green Project induced land cover change in the Loess Plateau: A case study with Ansai County, Shanxi Province, China. Ecol Indic. 23, 88, 2012.

37. WANG G., INNES J.L., LEI J., DAI S., WU S.W. China's forestry reforms. Science. 318, 1556, 2007.

38. STATISTICS BUREAU OF ANHUI PROVINCE (SBAH). Statistical Yearbook of Anhui province. ht t p://www.ahtjj.gov.cn/tjj/web/tjnj_view. jsp?strColId $=13787135717978521 \&$ _index $=1, \quad \mathbf{2 0 0 1 - 2 0 1 0}$ (in Chinese).

39. STATE FORESTRY ADMINISTRATION (SFA). China forestry development report. China Forestry Press, Beijing. 2000-2008.

40. BALDI G., GUERSCHMAN J.P., PARUELO J.M. Characterizing fragmentation in temperate South America grasslands. Agr Ecosyst Environ. 116, 197, 2006.

41. THOMPSON J.R., FOSTER D.R., SCHELLER R., KITTREDGE D. The influence of land use and climate change on forest biomass and composition in Massachusetts, USA. Ecol Appl. 21, 2425, 2011. 